\title{
Prediction of Differentiation Tendency Toward Hepatocytes from Gene Expression in Undifferentiated Human Pluripotent Stem Cells
}

\author{
Kana Yanagihara, ${ }^{1}$ Yujung Liu, ${ }^{1}$ Kei Kanie, Kazuo Takayama, ${ }^{3-5}$ Minako Kokunugi,,6 Mitsuhi Hirata, \\ Takayuki Fukuda, ${ }^{1}$ Mika Suga, Hiroki Nikawa, Hiroyuki Mizuguchi, ${ }^{3,5,7}$ Ryuji Kato, and Miho K. Furue ${ }^{1}$
}

\begin{abstract}
Functional hepatocytes derived from human pluripotent stem cells (hPSCs) have potential as tools for predicting drug-induced hepatotoxicity in the early phases of drug development. However, the propensity of hPSC lines to differentiate into specific lineages is reported to differ. The ability to predict low propensity of hPSCs to differentiate into hepatocytes would facilitate the selection of useful hPSC clones and substantially accelerate development of hPSC-derived hepatocytes for pharmaceutical research. In this study, we compared the expression of genes associated with hepatic differentiation in five hPSC lines including human ES cell line, H9, which is known to differentiate into hepatocytes, and an hPSC line reported with a poor propensity for hepatic differentiation. Genes distinguishing between undifferentiated hPSCs, hPSC-derived hepatoblast-like differentiated cells, and primary human hepatocytes were drawn by two-way cluster analysis. The order of expression levels of genes in undifferentiated hPSCs was compared with that in hPSC-derived hepatoblast-like cells. Three genes were selected as predictors of low propensity for hepatic differentiation. Expression of these genes was investigated in $23 \mathrm{hPSC}$ clones. Review of representative cells by induction of hepatic differentiation suggested that low prediction scores were linked with low hepatic differentiation. Thus, our model using gene expression ranking and bioinformatic analysis could reasonably predict poor differentiation propensity of hPSC lines.
\end{abstract}

Keywords: human embryonic stem cells, human induced pluripotent stem cells, cell differentiation, endoderm, hepatocyte

\section{Introduction}

$\mathrm{H}$ UMAN PLURIPOTENT STEM CELLS (hPSCs), including embryonic stem cells (hESCs) [1] and human induced pluripotent stem cells (hiPSCs) [2,3], are expected to be a promising cell reagents for basic biological research, cellbased medicine, and pharmaceutical development. It is because of their abilities to replicate indefinitely and to differentiate into most cell types in the body [4-6]. In phar- maceutical research, primary human hepatocytes are used as in vitro models to assess metabolism and toxicity of drug compounds. However, primary human hepatocytes cannot be passaged, rapidly lose their function [7], and are expensive. Functional hepatocytes derived from hPSCs have great potential as tools for modeling diseases [8,9], hepatitis infection [10-12], drug metabolism [13-18], fluid shear stress [19], and regeneration regenerative medicine [20]. Several protocols for hepatic differentiation of hPSCs have been reported

\footnotetext{
${ }^{1}$ Laboratory of Stem Cell Cultures and ${ }^{5}$ Laboratory of Hepatocyte Regulation, National Institutes of Biomedical Innovation, Health and Nutrition, Osaka, Japan.

${ }_{3}^{2}$ Department of Basic Medicinal Sciences, Graduate School of Pharmaceutical Sciences, Nagoya University, Nagoya, Japan.

${ }^{3}$ Laboratory of Biochemistry and Molecular Biology, Graduate School of Pharmaceutical Sciences, Osaka University, Osaka, Japan.

${ }^{4}$ The Keihanshin Consortium for Fostering the Next Generation of Global Leaders in Research (K-CONNEX), Kyoto University, Kyoto, Japan.

${ }^{6}$ Department of Oral Biology \& Engineering Integrated Health Sciences, Institute of Biomedical and Health Sciences, Hiroshima University, Hiroshima, Japan.

${ }^{7}$ Global Center for Medical Engineering and Informatics, Osaka University, Osaka, Japan.

(C) Kana Yanagihara, et al., 2016; Published by Mary Ann Liebert, Inc. This Open Access article is distributed under the terms of the Creative Commons Attribution Noncommercial License (http://creativecommons.org/licenses/by-nc/4.0/) which permits any noncommercial use, distribution, and reproduction in any medium, provided the original author(s) and the source are credited.
} 
[13,21-33]. Previously the Mizuguchi lab developed efficient methods to differentiate hPSCs into functional hepatocytelike cells using adenovirus vector-mediated overexpression of hepatocyte linage-related transcription factors [34-39]. Because adenovirus vectors are the most efficient among gene delivery vehicles that can provide high transduction efficiency in both dividing and nondividing cells, the differentiation into hepatocytes should be relatively stable [40]. However, expression levels of metabolic enzymes vary between hPSC-derived hepatocyte-like cells that are derived from even a donor cell line [35,38]. Previous studies demonstrated that individual hPSC lines have distinct propensities to differentiate into specific lineages [41-45]. hESCs generated from various donors by different methods display phenotypic variation. Variation in hiPSC clones even arise from a single donor. Gene expression profiles revealed that phenotypes of hepatocytes derived from hPSCs using differentiation protocols reported until now are still immature $[32,46]$. Selection of good hPSC lines or clones by identifying clones exhibiting low propensity to differentiate into hepatocytes would substantially accelerate application of hPSCderived hepatocytes in pharmaceutical research. Several studies demonstrated that variation in hepatic differentiation can be attributed either to differences between donors [47] or epigenetic memory $[48,49]$. Hepatic differentiation propensity was recently reported to be affected by alterations in nuclear receptor genes [50].

We hypothesized that variations in hepatocyte differentiation efficiency can be predicted by studying the gene expression profile of undifferentiated hPSCs. Although DNA arrays can provide fundamental information, analysis of the resulting data is very time-, labor-, and cost- intensive. In this study gene expression of the following five representative hPSC lines was compared using polymerase chain reaction (PCR) arrays and bioinformatic analysis: H9, which is known to differentiate well [24,29-33,3537,39,46]; Tic and Dotcom, both of which were reported to differentiate well $[34,35,37]$; Squeaky, which was derived from the same donor cell line as Tic and Dotcom; and 201B7, which was reported to have a poor propensity for hepatic differentiation $[38,47]$. We particularly focused on genes encoding hepatocyte linage markers and growth factors involved in differentiation, and endoderm differentiation signaling pathways including PI3K-AKT signaling, WNT signaling, and TGF $\beta / B M P$ signaling. This analysis suggested three candidate genes, the low expression of which may be associated with low propensity for hepatic differentiation. We then examined expression patterns in $23 \mathrm{hPSC}$ clones to estimate their hepatic differentiation potential. Using this approach based on gene expression ranking and bioinformatic analysis, we could reasonably predict lower propensity for hepatic differentiation.

\section{Materials and Methods}

\section{Ethics statement}

hESCs were used following the "Guidelines for Utilization of Human Embryonic Stem Cells" of the Ministry of Education, Culture, Sports, Science and Technology of Japan after approval by the Institutional Ethical Review Board of the National Institutes of Biomedical Innovation, Health, and Nutrition. Experiments using human iPSCs were conducted with the approval of the Institutional Review Board of the National Institutes of Biomedical Innovation, Health, and Nutrition.

\section{Cell culture}

Eight hESC lines: H9 (WA09), HES3, HES4, KhES-1, KhES-2, KhES-3, KhES-4, and KhES-5; and 13 hiPSC lines: 201B7, 201B6, 201B2, 253G1B1, iPS-TIG108-4f3, iPS-TIG114-4f1 (JCRB1437), iPS-TIG120-4f1 (JCRB1363), Tic (JCRB1331), Dotcom (JCRB1327), Squeaky (JCRB1329), Toe (JCRB1338), UTA1, iPS-DF19-9-7T, and its karyotypically aberrant subclone (19-9-7Tv) were used in this study. Detailed information about these cell lines and their maintaining culture conditions is provided in Supplementary Table S1 and Supplementary Materials and Methods (Supplementary Data are available online at www.liebertpub $. \mathrm{com} / \mathrm{scd}$ ). In brief, hPSCs were routinely maintained on inactivated mouse embryonic fibroblast feeder cells (Merck Millipore, Darmstadt, Germany) in knockout serum replacement (KSR)-based medium supplemented with 4-10 ng/mL human recombinant FGF-2 (Katayama Chemical Industries Co., Ltd., Osaka, Japan) as previously described [3,51-53]. H9, Tic, 201B7, 201B6, and 253G1B1 were cultured in an animal product-free defined medium, hESF-FX (PCT/ JP2011/004691)[54] modified from a growth factor defined culture medium, hESF9, which we previously developed for culturing hESCs [55], without feeder cells on $2 \mu \mathrm{g} / \mathrm{cm}^{2}$ bovine fibronectin [34,53,55-58] (Supplementary Data). hiPSCs, iPS-DF19-9-7T and iPS-DF19-9-7Tv were cultured in mTeSR1 on Matrigel ${ }^{\mathrm{TM}}$ according to the manufacturer's instructions (STEMCELL Technologies, Inc., Vancouver, Canada).

\section{Primary human hepatocyte culture}

Cryopreserved human primary hepatocytes (VERITAS) were cultured according to the manufacturer's instructions. The hepatocytes were seeded at $1.25 \times 10^{5}$ cells $/ \mathrm{cm}^{2}$ in hepatocyte culture medium (HCM; Lonza, Walkersville, MD) containing 10\% fetal bovine serum (FBS; Thermo Fisher Scientific) onto type I collagen (Nitta Gelatin)-coated plates. The medium was replaced at $6 \mathrm{~h}$ after seeding. The hepatocytes, which were cultured $48 \mathrm{~h}$ after plating the cells, were used in the experiments.

\section{Differentiation of hPSCs into hepatoblast-like cells}

hPSCs were differentiated toward hepatoblast-like cells according to a previously reported differentiation protocol [30,59] with minor modifications. In brief, hPSCs were dissociated into single cells using Accutase (Merck Millipore) and then plated at 600,000 cells per well in 24-well plates (BD Falcon, Franklin Lakes, NJ) precoated with $4 \mu \mathrm{g} /$ $\mathrm{cm}^{2}$ bovine fibronectin (Sigma-Aldrich, St. Louis, MO). The cells were cultured with chemically defined medium (CDM) consisting of 50\% IMDM (Thermo Fisher Scientific) plus 50\% F-12 Nutrient Mixture (Thermo Fisher Scientific), $7 \mu \mathrm{g} / \mathrm{mL}$ insulin (Roche Diagnostics), $15 \mu \mathrm{g} / \mathrm{mL}$ transferrin (Roche Diagnostics), $450 \mu \mathrm{M}$ monothioglycerol (SigmaAldrich), and $5 \mathrm{mg} / \mathrm{mL}$ bovine serum albumin fraction $\mathrm{V}$ (Wako Pure Chemical Industries, Ltd., Osaka, Japan), supplemented with $10 \mathrm{ng} / \mathrm{mL}$ activin A (R\&D Systems, MN) and $12 \mathrm{ng} / \mathrm{mL}$ FGF-2 for 2 days. For the following 3 days, 
cells were cultured with $10 \mu \mathrm{M}$ Ly294002 (Cell Signaling Technology, Beverly, MA), $100 \mathrm{ng} / \mathrm{mL}$ activin A, $20 \mathrm{ng} / \mathrm{mL}$ FGF-2, and $10 \mathrm{ng} / \mathrm{mL}$ BMP-4 (R\&D Systems). The cells were cultured for 3 days in the presence of $50 \mathrm{ng} / \mathrm{mL}$ FGF10 (R\&D Systems) and then treated with $0.1 \mu \mathrm{M}$ retinoic acid (Sigma-Aldrich), $10 \mu \mathrm{M} \mathrm{SB} 431542$ (Tocris Bioscience, Bristol, United Kingdom), and $50 \mathrm{ng} / \mathrm{mL}$ FGF-10 for 2 days. Finally, the cells were cultured in CDM supplemented with $30 \mathrm{ng} / \mathrm{mL}$ FGF-4 (R\&D Systems), $50 \mathrm{ng} / \mathrm{mL}$ hepatocyte growth factor (HGF; R\&D Systems), and $50 \mathrm{ng} / \mathrm{mL}$ epidermal growth factor (EGF; R\&D Systems) for an additional 20 days.

\section{Differentiation of hPSCs into hepatocyte-like cells}

To confirm hepatic differentiation tendency of hPSC H9, KhES4, KhES3, and 201B7 maintained under KSR-based culture conditions, and 19-9-7T and its aberrant clone maintained under mTeSR1 culture conditions were differentiated toward hepatocyte-like cells according to previously reported differentiation protocol [31,60-62] with minor modifications. Briefly, dissociated hPSCs were cultured onto Matrigel Basement Membrane Matrix Growth Factor Reduced (Corning) in the MEF-conditioned medium for 3-4 days. Then, the cells were cultured for 4 days with the L-WNT3A-expressing cell (CRL2647; ATCC)conditioned RPMI1640 medium (Sigma) containing $100 \mathrm{ng} /$ mL Activin A (R\&D Systems), 1\% GlutaMAX (Thermo Fisher Scientific), $0.2 \% \mathrm{FBS}$, and $1 \times$ B27 Supplement Minus Vitamin A (Thermo Fisher Scientific). The hPSCderived definitive endoderm cells were cultured with RPMI1640 medium containing $30 \mathrm{ng} / \mathrm{mL}$ bone morphogenetic protein 4 (BMP4; R\&D Systems) and $20 \mathrm{ng} / \mathrm{mL}$ FGF-4 (R\&D Systems), $1 \%$ GlutaMAX, and $1 \times$ B27 Supplement Minus Vitamin A for 5 days. Next, the hPSC-derived hepatoblasts were cultured with RPMI1640 medium containing $20 \mathrm{ng} / \mathrm{mL}$ HGF (R\&D Systems), $1 \%$ GlutaMAX, and $1 \times$ B27 Supplement Minus Vitamin A for 5 days. Finally, the cells were cultured with the hepatic maturation medium (hepatic maturation medium consists of HCM (Lonza, without EGF) containing $20 \mathrm{ng} / \mathrm{mL}$ oncostatin M (OsM) and $3 \%$ GlutaMAX) for 11 days.

To confirm hepatic differentiation tendency of hPSC, H9, 253G1B1, and 201B7 after culturing in hESF-FX medium for more than five passages, the hPSCs were differentiated toward hepatocyte-like cells according to another previously reported differentiation protocol $[31,60,61]$ with minor modifications. In brief, hPSCs dissociated with Accutase were seeded at a density of 600,000 cells per well in 24-well plates precoated with $300 \mu \mathrm{L} /$ well Geltrex (Thermo Fisher Scientific) and cultured with mTeSR1 medium (Stemcell Technologies, Vancouver, Canada) in $4 \% \quad \mathrm{O}_{2} / 5 \% \quad \mathrm{CO}_{2}$. Approximately $24 \mathrm{~h}$ after seeding, when the cells were $85 \%-$ $95 \%$ confluent, the medium was changed to RPMI1640 medium (Thermo Fisher Scientific) supplemented with B27 minus insulin, $100 \mathrm{ng} / \mathrm{mL}$ activin A, $10 \mathrm{ng} / \mathrm{mL}$ BMP-4, and $20 \mathrm{ng} / \mathrm{mL}$ FGF-2 in ambient $\mathrm{O}_{2} / 5 \% \mathrm{CO}_{2}$ for 2 days. The cells were cultured in RPMI1640 medium supplemented with B27 minus insulin and $100 \mathrm{ng} / \mathrm{mL}$ activin $\mathrm{A}$ for the following 3 days in ambient $\mathrm{O}_{2} / 5 \% \mathrm{CO}_{2}$. The medium was changed daily. Cells were cultured in RPMI1640 supplemented with B27 supplement (Thermo Fisher Scientific),
$20 \mathrm{ng} / \mathrm{mL}$ BMP-4, and $10 \mathrm{ng} / \mathrm{mL}$ FGF-2 for 5 days in $4 \%$ $\mathrm{O}_{2} / 5 \% \mathrm{CO}_{2}$. The medium was changed daily. Then, the medium was replaced with RPMI1640 supplemented with B27 supplement and $20 \mathrm{ng} / \mathrm{mL} \mathrm{HGF}$, and the cells were cultured for 5 days in $4 \% \mathrm{O}_{2} / 5 \% \mathrm{CO}_{2}$. Finally, the medium was replaced with Hepatocyte Culture Media (Lonza, Basel, Switzerland) containing SingleQuots omitting the EGF with $20 \mathrm{ng} / \mathrm{mL}$ Oncostatin-M (R\&D Systems), and the cells were cultured for 5 days in ambient $\mathrm{O}_{2} / 5 \% \mathrm{CO}_{2}$.

\section{Albumin secretion}

During the final differentiation step described above, cell culture supernatant of the hPSC-derived hepatocyte-like cells was collected every $24 \mathrm{~h}$ to measure albumin secretion. The primary human hepatocytes were cultured for $24 \mathrm{~h}$ and their culture supernatant was collected to measure albumin secretion. The human albumin content of the supernatant was determined using a Human Albumin ELISA Quantitation kit, according to the manufacturer's instructions (Bethyl Laboratories, Montgomery, TX). Albumin secretion was normalized to the total RNA of the cells from which culture supernatant was collected.

\section{Urea production}

The culture supernatants, which were incubated for $24 \mathrm{~h}$ after fresh medium was added, were collected and analyzed for the amount of urea production. Urea measurement kits were purchased from BioAssay Systems. The experiment was performed according to the manufacturer's instructions. The amount of urea secretion was calculated according to each standard followed by normalization to the RNA content.

\section{CYP3A4 activity}

To measure the cytochrome P450 3A4 activity of the hepatocyte-like cells and primary hepatocytes, we performed lytic assays by using a P450-GloTM 3A4 (catalog number; V9001) Assay Kit (Promega). We measured the fluorescence activity with a luminometer (Lumat LB 9507; Berthold) according to the manufacturer's instructions. The CYP activity was normalized with the RNA content.

\section{Immunocytochemical staining}

Immunocytochemistry was performed as described previously [56,57]. The primary and secondary antibodies used in this study are listed in Supplementary Table S2. Image analysis was performed using In Cell analyzer 2000 and Developer Toolbox software (GE Healthcare UK Ltd., Little Chalfont, United Kingdom).

\section{Gene expression analysis}

Total RNA was isolated from hPSCs, hepatoblast-like cells, hepatocyte-like cells, HepG2 cells, and adult hepatocytes using the RNeasy Mini Kit or RNeasy Micro Kit (Qiagen, Valencia, CA) and treated with DNase I (Qiagen) to remove any genomic contamination. For real-time PCR, $500 \mathrm{ng}$ RNA was used for reverse transcription with $\mathrm{Su}-$ perscript VILO cDNA Synthesis Kit (Thermo Fisher 
Scientific). PCR was performed based on the TaqMan or SYBR green gene expression technology in a 7300 RealTime PCR System (Thermo Fisher Scientific), following the manufacturer's instructions. Threshold cycles were normalized to the housekeeping genes glyceraldehyde-3phosphate dehydrogenase (GAPDH), beta-2-microglobin $(B 2 M)$, and hypoxanthine phosphoribosyltransferase 1 (HPRT1) and translated to relative values. Specific primers used are listed in Supplementary Table S3.

For PCR array, 500 ng of RNA of the cells and total RNA of human fetal and adult liver (Clontech Laboratories, Takara Bio USA, Inc., Mountain View, CA) was used for reverse transcription with $\mathrm{RT}^{2}$ First Strand Kit (Qiagen) or High Capacity RNA-to-cDNA kit (Thermo Fisher Scientific) for $\mathrm{RT}^{2}$ Profiler ${ }^{\mathrm{TM}}$ PCR Array or TaqMan Array, respectively. The expression of genes was determined using $\mathrm{RT}^{2}$ Profiler ${ }^{\mathrm{TM}}$ PCR Array with $\mathrm{RT}^{2}$ SYBR Green/ROX qPCR Master Mix (Qiagen) or using TaqMan Array with an ABI7900 HTR-PF (Thermo Fisher Scientific). The PCR Arrays used in this study included Human PI3K-AKT Signaling Pathway $\mathrm{RT}^{2}$ Profiler PCR Array (87 genes), Human TGF $\beta$ /BMP Signaling Pathway RT ${ }^{2}$ Profiler PCR Array (87 genes), Human Growth Factors RT ${ }^{2}$ Profiler PCR Array (87 genes), Human WNT Signaling Pathway RT $^{2}$ Profiler PCR Array (87 genes), and Custom PCR array (122 genes related to hepatic differentiation and six endogenous control genes; Qiagen), described in Supplementary Table S4. Expression of stem cell markers and three germ markers was investigated using TaqMan Human Stem Cell Pluripotency Array (92 genes and 6 endogenous control genes, Thermo Fisher Scientific) with TaqMan Gene Expression Master Mix (Thermo Fisher Scientific) and ABI7900HT Fast Real-Time PCR systems (Thermo Fisher Scientific) as previously described [41]. Expression levels of all target genes were normalized to housekeeping genes GAPDH, B2M, and HPRT1. All data analysis was followed by bioinformatics analysis.

\section{Bioinformatics analysis}

The bioinformatics analysis flow is summarized in Supplementary Fig. S1. Data were analyzed using DataAssist ${ }^{\mathrm{TM}}$ Software v3.01 (Thermo Fisher Scientific) for RT $^{2}$ Profiler ${ }^{\mathrm{TM}}$ PCR Array (Human PI3K-AKT Signaling Pathway, Human TGF $\beta$ /BMP Signaling Pathway, and Human Growth Factors, Human WNT Signaling Pathway) and Custom PCR array. Data were also analyzed using EspressionSuite v1.0.3 (Thermo Fisher Scientific) for TaqMan Human Stem Cell Pluripotency Array. For clustering analysis, normalization of $\triangle \mathrm{C}_{\mathrm{t}}$ values was based on three reference genes (GAPDH, $B 2 M$, and HPRTI) in $\mathrm{RT}^{2}$ Profiler ${ }^{\mathrm{TM}}$ PCR Array and Custom array and three reference genes (18S ribosomal RNA, beta-actin, and GAPDH) in TaqMan Human Stem Cell Pluripotency Array. Both analyses were completed following standard protocols. Normalization of relative quantification was based on 201B7. Median fold change was calculated as a score from each gene category $[63,64]$. For example, the score for endoderm in H9 (1.08) was a median fold change of 18 for endoderm marker genes. For hierarchical clustering analysis (average linkage), Cluster 3.0 v1.50 (http:// bonsai.hgc.jp/ $\sim$ mdehoon/software/cluster/software.htm) was used and for visualization, Java TreeView v1.1.6r2 (http:// jtreeview.sourceforge.net) was used.

\section{Results}

\section{Differentiation of hepatic lineage in five hPSC lines}

We computed an average gene expression score for the propensity for hepatic differentiation of the five hPSC lines H9, which is known to differentiate well [24,29-33,3537,39,46]; Tic and Dotcom, both of which are reported to differentiate well $[34,35,37]$; Squeaky, which was derived from the same donor cell line as Tic and Dotcom; and 201B7, which is reported to have a poor propensity for hepatic differentiation [47]. We used a custom PCR array to assess gene expression in hepatoblast-like differentiated hPSCs that were induced using a slightly modified previously reported growth factor-mediated differentiation protocol $[30,59]$. The gene list of the array included markers associated with undifferentiated stem cells, endoderm, and hepatic differentiation. Differentiation of each cell line was scored according to the expression levels of genes associated with endoderm and hepatic differentiation lineage in the custom PCR array (Table 1). The gene expression profiles showed that H9, Dotcom, and Tic had higher scores than 201B7 or Squeaky (H9, Dotcom, Tic >> Squeaky, 201B7), as previously described $[34,35,37]$.

\section{Differentially expressed genes in hepatoblast-like cells derived from hPSCs}

To compare characteristics of hPSC-derived hepatoblastlike cells, genes that were differentially expressed between hepatoblast-like differentiated and undifferentiated hPSC lines were examined using a custom PCR array analysis of undifferentiated hPSCs. The gene expression profiles of undifferentiated hPSCs, hPSC-derived hepatoblast-like differentiated cells, HepG2 cells, primary human fetal hepatocytes, and human adult hepatocytes were analyzed using two-way cluster analysis (Fig. 1). This analysis indicated that cells were divided into the following three groups: "undifferentiated hPSCs" (undifferentiated state of Dotcom, 201B7, Squeaky, H9, and Tic), "differentiated hPSCs" (hepatoblast-like cells from Dotcom, 201B7, Squeaky, H9, and Tic), and "hepatocytes" (HepG2, fetal hepatocytes, and adult hepatocytes). Differentially expressed genes were divided into four groups, designated clusters A, B, $\mathrm{C}$, and D. Among them, the "hepatocyte" group expressed comparatively higher levels of clusters A and B genes. Further analysis of cluster B genes indicated that all "differentiated hPSCs" studied here could not be distinguished from "hepatocytes" (Supplementary Fig. S2). Therefore, expression of the 15 cluster B genes did not differ significantly among "differentiated hPSCs." Next, expression of cluster A genes analyzed by two-way cluster analysis indicated that cells were clearly separated into two groups (Fig. 2). Two "differentiated hPSCs," 201B7- and Squeaky-derived differentiated cells, belonged to a group with "undifferentiated hPSCs," whereas the other "differentiated hPSCs," H9-, Tic-, and Dotcom-derived differentiated cells belonged to another group with "hepatocytes." These results indicated that expression of cluster A genes differed among "differentiated hPSCs." Thus, 201B7- and Squeakyderived hepatoblast-like cells were less differentiated compared with the others. 
TABle 1. ScORES OF ENDODERMand HePatocyte-Related Gene Expression in the Hepatic Differentiation of Each Human Pluripotent Stem Cell Line

\begin{tabular}{|c|c|c|c|c|c|}
\hline \multirow[b]{2}{*}{ Gene } & \multicolumn{5}{|c|}{ Cell line } \\
\hline & H9 & Tic & Dotcom & Squeaky & $201 B 7$ \\
\hline$A B C B 11$ & 1.13 & 1.74 & 16.65 & 4.57 & 1.00 \\
\hline$A B C C 1$ & 0.71 & 0.60 & 1.51 & 1.29 & 1.00 \\
\hline$A B C C 2$ & 17.24 & 4.26 & 2.52 & 1.92 & 1.00 \\
\hline$A B C C 3$ & 1.83 & 2.12 & 2.62 & 2.58 & 1.00 \\
\hline АВСС 6 & 9.28 & 3.97 & 3.67 & 0.84 & 1.00 \\
\hline$A B C D 4$ & 1.92 & 2.05 & 2.43 & 2.24 & 1.00 \\
\hline$A D H I A$ & 2.00 & 0.11 & 0.45 & 1.48 & 1.00 \\
\hline$A F P$ & 121.43 & 85.86 & 33.45 & 13.31 & 1.00 \\
\hline$A L B$ & 131.11 & 71.44 & 43.21 & 2.10 & 1.00 \\
\hline$A L D H 1 A 3$ & 0.77 & 0.51 & 0.39 & 1.24 & 1.00 \\
\hline ALDH8A1 & 1.70 & 1.09 & 2.98 & 3.69 & 1.00 \\
\hline$A L D O B$ & 284.26 & 36.83 & 11.09 & 2.90 & 1.00 \\
\hline APOA & 17.56 & 14.27 & 7.24 & 2.75 & 1.00 \\
\hline$A P O F$ & 28.64 & 6.14 & 8.78 & 0.25 & 1.00 \\
\hline$A S G R 1$ & 22.51 & 13.05 & 4.41 & 1.55 & 1.00 \\
\hline C3 & 2.61 & 1.01 & 1.52 & 12.28 & 1.00 \\
\hline CDKN1A & 1.21 & 2.15 & 2.03 & 1.28 & 1.00 \\
\hline СЕАСАМ1 & 2.60 & 4.55 & 3.40 & 4.39 & 1.00 \\
\hline СЕВРА & 6.31 & 0.64 & 1.57 & 0.69 & 1.00 \\
\hline$C E B P B$ & 1.18 & 0.44 & 1.34 & 1.76 & 1.00 \\
\hline CPS1 & 1.36 & 3.57 & 1.37 & 1.39 & 1.00 \\
\hline CTNNB1 & 1.03 & 0.68 & 1.22 & 2.19 & 1.00 \\
\hline CYPIA1 & 0.84 & 0.10 & 1.92 & 1.84 & 1.00 \\
\hline CYP1A2 & 4.16 & 4.72 & 4.07 & 1.90 & 1.00 \\
\hline CYP26B1 & 13.86 & 0.21 & 1.24 & 6.28 & 1.00 \\
\hline СYР27A1 & 0.55 & 0.52 & 1.96 & 2.52 & 1.00 \\
\hline СYР2B6 & 5.69 & 0.04 & 4.79 & 2.70 & 1.00 \\
\hline СYР2С19 & 6.70 & 2.04 & 1.50 & 2.02 & 1.00 \\
\hline СУР2C8 & 0.75 & 2.98 & 1.96 & 2.82 & 1.00 \\
\hline СУР2С9 & 217.80 & 4.66 & 153.61 & 60.35 & 1.00 \\
\hline CYP2D6 & 2.26 & 1.42 & 1.92 & 3.56 & 1.00 \\
\hline CYP2E1 & 0.54 & 0.84 & 0.48 & 0.10 & 1.00 \\
\hline CYP2R1 & 3.34 & 3.94 & 2.89 & 1.67 & 1.00 \\
\hline CYP2S1 & 1.09 & 0.59 & 1.89 & 3.29 & 1.00 \\
\hline СУРЗА4 & 12.45 & 36.24 & 1.86 & 0.49 & 1.00 \\
\hline СYР3А5 & 4.55 & 4.20 & 1.71 & 1.14 & 1.00 \\
\hline СYР $3 A 7$ & 1.61 & 2.86 & 2.06 & 1.38 & 1.00 \\
\hline CYP4B 1 & 39.43 & 19.38 & 0.69 & 1.31 & 1.00 \\
\hline СYРТА & 0.47 & 0.37 & 0.56 & 0.15 & 1.00 \\
\hline СYР7В1 & 2.76 & 5.28 & 3.01 & 3.81 & 1.00 \\
\hline DPP4 & 3.47 & 3.96 & 5.36 & 3.81 & 1.00 \\
\hline G6РC & 182.56 & 62.11 & 6.93 & 1.53 & 1.00 \\
\hline GATA4 & 2.13 & 0.70 & 2.17 & 2.25 & 1.00 \\
\hline GJA1 & 1.43 & 2.71 & 3.35 & 1.97 & 1.00 \\
\hline GJB1 & 24.25 & 3.46 & 5.64 & 1.19 & 1.00 \\
\hline$H N F 1 A$ & 7.14 & 2.90 & 7.49 & 5.38 & 1.00 \\
\hline ITGA6 & 1.74 & 1.68 & 2.28 & 1.94 & 1.00 \\
\hline KRT18 & 1.46 & 0.97 & 1.43 & 1.73 & 1.00 \\
\hline$K R T 8$ & 1.29 & 0.53 & 1.08 & 1.86 & 1.00 \\
\hline LST1 & 7.88 & 11.16 & 3.35 & 5.72 & 1.00 \\
\hline$M E T$ & 2.48 & 2.18 & 2.04 & 2.35 & 1.00 \\
\hline$N R 1 / 2$ & 1.65 & 1.23 & 0.86 & 0.59 & 1.00 \\
\hline$N R 1 / 3$ & 5.44 & 2.20 & 2.28 & 3.06 & 1.00 \\
\hline$P C K 1$ & 78.72 & 21.07 & 10.52 & 0.35 & 1.00 \\
\hline$P O R$ & 1.06 & 0.47 & 1.17 & 1.78 & 1.00 \\
\hline PROX1 & 1.65 & 3.30 & 4.01 & 2.81 & 1.00 \\
\hline SERPINAI & 37.54 & 46.04 & 33.90 & 18.32 & 1.00 \\
\hline
\end{tabular}

(continued)
TABle 1. (CONTINUED)

\begin{tabular}{lrrrrr}
\hline & \multicolumn{5}{c}{ Cell line } \\
\cline { 2 - 6 } Gene & \multicolumn{1}{c}{ H9 } & \multicolumn{1}{c}{ Tic } & Dotcom & Squeaky & $201 B 7$ \\
\hline SLCO4A1 & 5.13 & 0.13 & 0.22 & 2.01 & 1.00 \\
SULT2A1 & 19.46 & 3.41 & 3.21 & 0.26 & 1.00 \\
TAT & 0.36 & 0.10 & 0.64 & 0.35 & 1.00 \\
TDO2 & 3.02 & 4.37 & 4.15 & 0.62 & 1.00 \\
TF & 2.45 & 0.62 & 0.25 & 0.10 & 1.00 \\
TGFBR2 & 0.92 & 0.98 & 1.93 & 1.53 & 1.00 \\
TTR & 13.04 & 12.81 & 8.69 & 4.42 & 1.00 \\
UGT1A1 & 625.78 & 721.75 & 402.54 & 91.51 & 1.00 \\
SCORE & 2.61 & 2.20 & 2.28 & 1.94 & 1.00 \\
\hline
\end{tabular}

The hPSC lines were treated with a previously reported growth factor-mediated differentiation protocol toward hepatoblast-like [30,59] cells with minor modifications. Gene expression in the hPSCs was analyzed using the custom PCR array (122 genes) including markers associated with undifferentiated stem cells, endoderm, and hepatic differentiation (Supplementary Table S4). Differentiation levels were scored according to the expression levels of genes (65 genes) associated with endoderm and hepatic differentiation lineage in the custom PCR array. The mean of gene expression levels of five independent experiments were used for the analysis.

hPSCs, human pluripotent stem cells; PCR, polymerase chain reaction.

\section{Gene ranking of undifferentiated and differentiated hPSCs}

We hypothesized that the ranking of cluster A gene expression levels in hPSC-derived hepatocyte-like cells (H9, Tic, Dotcom >>201B7, Squeaky) may be associated with the ranking of other genes expressed in undifferentiated hPSCs. To investigate gene expression markers of similar ranking in undifferentiated hPSCs average linkage hierarchical clustering was performed for 122 genes in the custom PCR array in undifferentiated hPSCs, together with 22 cluster A genes in the hPSC-derived hepatoblast-like cells (Supplementary Figs. S3 and S5). Furthermore, cluster analysis was also performed for hepatic differentiationassociated genes and cell signaling-associated genes (348 genes, Supplementary Figs. S4 and S6) using Human PI3KAKT Signaling Pathway RT $^{2}$ Profiler PCR Array, Human TGF $\beta /$ BMP Signaling Pathway RT $^{2}$ Profiler PCR Array, Human Growth Factors RT $^{2}$ Profiler PCR Array, and Human WNT Signaling Pathway $\mathrm{RT}^{2}$ Profiler PCR Array in undifferentiated hPSCs, together with cluster A genes (22 genes) in differentiated hPSCs. Expression levels of target genes were normalized to housekeeping genes GAPDH, $B 2 M$, and HPRT because other housekeeping genes, RPL13A and HGDC were unstable. We found the expression patterns of six genes in undifferentiated hPSCs were clustered with cluster A genes in the hPSC-derived hepatoblast-like cells (CYP2E1, HNF1A, HNF1B, HNF4A, ONECUT-1, and PDX-1) (Supplementary Fig. S3), and eight cell signaling-associated genes in the undifferentiated hPSCs were positively associated with cluster A genes in the hPSC-derived hepatoblast-like cells (CSF2, FASLG, FGF-1, FGF-17, FGF-7, MSTN, RHOU, and TYMP) (Supplementary Fig. S4). Next, to investigate possible inverse ranking of the cells according to gene expression levels, cluster analysis was performed separately (Supplementary Figs. S5 


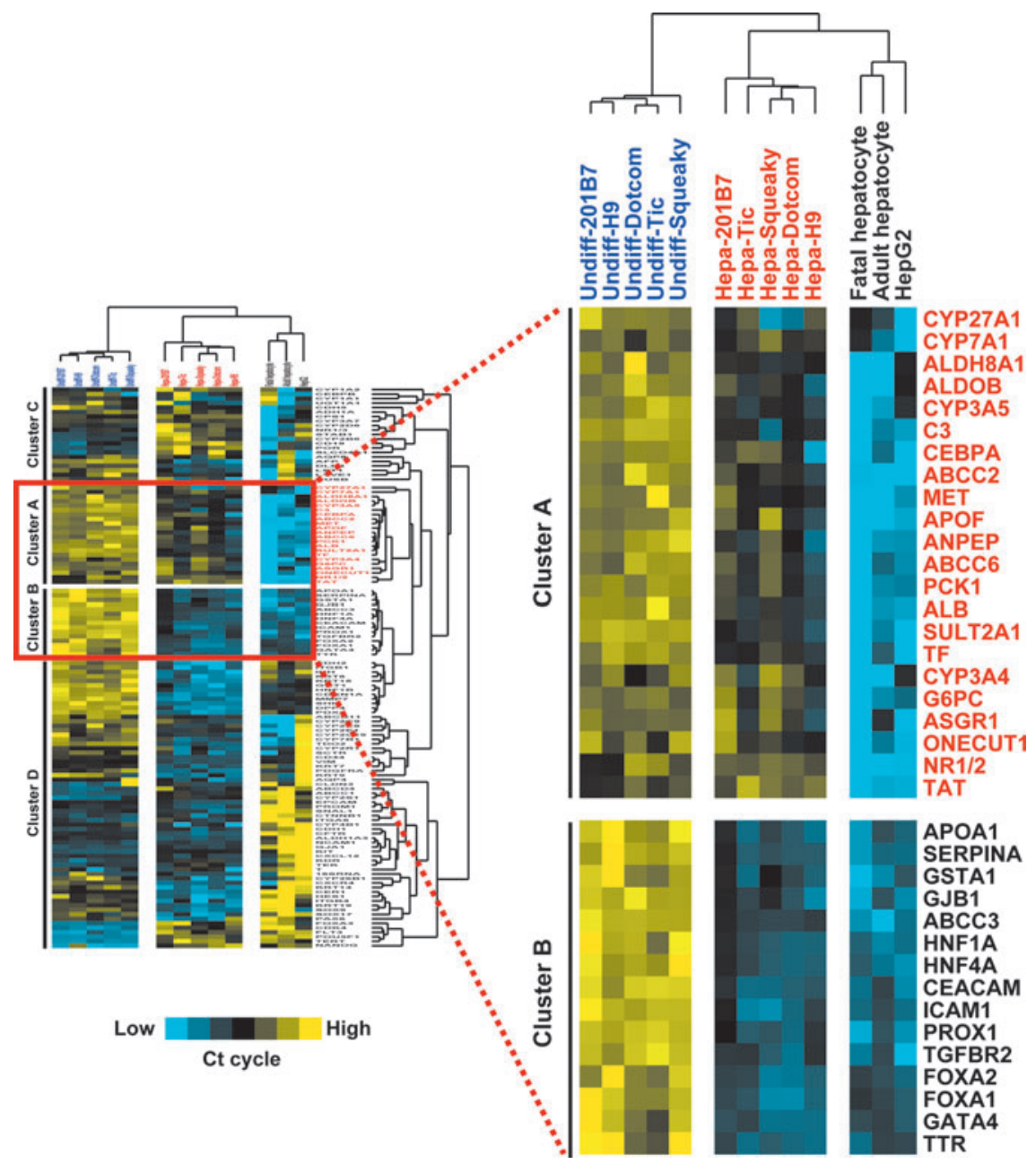

FIG. 1. Two-way cluster analysis of gene expression in undifferentiated and hepatocyte-like differentiated hPSC lines, HepG2, and primary fetal and adult hepatocytes. Thirteen cell types, undifferentiated (blue) and hepatocytelike differentiated (red) hPSC lines, HepG2, and fetal (black) and adult human hepatocytes (black) were separated into three groups; 122 genes were separated into four groups, cluster A, cluster B, cluster $\mathrm{C}$, and cluster D. Yellow color indicates high levels of gene expression, and blue color indicates low levels of gene expression. The mean of gene expression levels of five independent experiments were used for the analysis. hPSC, human pluripotent stem cell. and S6). The expression of two genes in undifferentiated hPSCs was inversely correlated with cluster A genes in the hPSC-derived hepatoblast-like cells ( $C X C L-12$ and $T F$ ) (Supplementary Fig. S5) while the expression of four cell signaling-associated genes in undifferentiated hPSCs was inversely correlated with cluster A genes in the hPSCderived hepatoblast-like cells (IGF-1, PIK3R2, RHEB, and SFRP-4) (Supplementary Fig. S6). Expression levels of these 20 genes were summarized in Table 2 . The genes that were highly expressed (lower than 10 in $\Delta \mathrm{Ct}$ values) or differed significantly between hPSC lines (higher than 0.4 in SD values) were selected among the 20 genes. Then, three genes, fibroblast growth factor-1 (FGF-1), ras homolog family member $U(R H O U)$, and thymidine phosphorylase $(T Y M P)$, were chosen as candidate genes linking ranking of gene expression levels in the hPSC-derived hepatoblastlike cells.

\section{Prediction of low hPSC differentiation propensity for hepatic lineage based on the expression of three candidate genes}

To test whether these candidate genes could be used to predict low hepatic lineage differentiation propensity in hPSC lines, gene expression in 23 hPSC lines cultured under KSR-based or several serum-free culture conditions was measured by real-time PCR. $\triangle \mathrm{Ct}$ values of $F G F-1, R H O U$, and TYMP in the hPSC lines were arranged in ascending order in Supplementary Table S5. Among the 21 hPSC lines cultured under KSR-based culture conditions with MEF, $\triangle \mathrm{Ct}$ values of these three genes in hPSC lines were compared with those in $\mathrm{H} 9$, which is known to have a comparatively higher propensity [24,29-33,35-37,39,46] for hepatocyte differentiation, and 201B7, which is reported to have a low propensity $[38,47]$. Cell lines with $\Delta \mathrm{Ct}$ values higher than those of 201B7 were grouped into the lower gene expression group (red). Cell lines with $\Delta \mathrm{Ct}$ values lower than those of H9 were grouped into the higher gene expression group (blue). Next, cell lines grouped into the lower group were scored -1 , whereas cells lines grouped into the higher group were scored +1 . The total scores for the genes were calculated for each cell line, and the cell lines were arranged in ascending order in Table 3. Gene expression in 253G1B1 cells and Squeaky cells resembled that in 201B7 cells while the prediction score of the HES4 line, which is reported to have a high propensity for hepatic differentiation [47], was similar to that of H9. Interestingly, gene expression in the three MRC-5-derived lines, Squeaky, Dotcom, and Tic, closely resembled one another even though Dotcom and Tic exhibited higher hepatic differentiation propensities than Squeaky. Our gene expression data described above demonstrated that Tic differentiated into hepatoblast-like cells. Previous studies demonstrated that Dotcom and Tic differentiated well [34,35,37]. These 


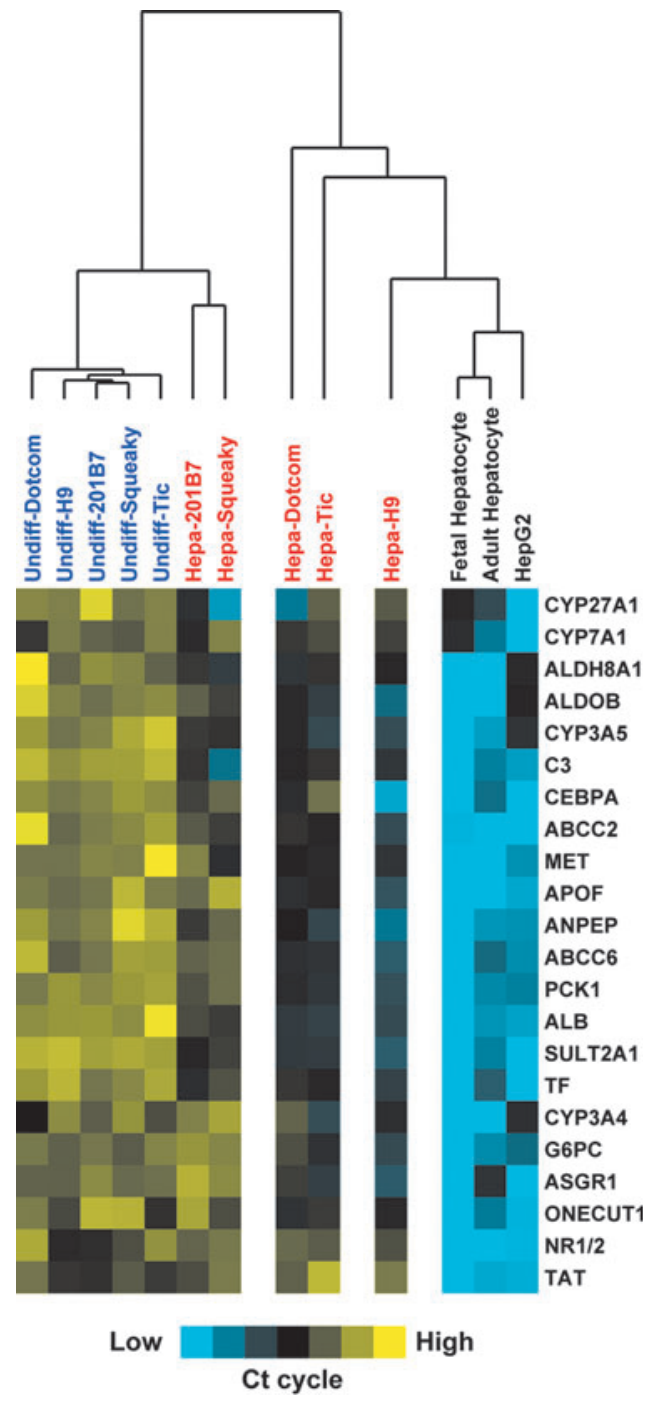

FIG. 2. Cluster analysis of 22 genes related to hepatic differentiation propensity in 13 cell types. The 22 genes were selected from 122 hepatocyte lineage-related genes, which distinguished gene expression in hepatoblast-like differentiated cells of five hPSCs. Hierarchical clustering of 13 cell types, undifferentiated hPSCs lines (blue), hPSCderived hepatoblast-like differentiated hPSC lines (red), primary fetal (black) and adult human hepatocytes (black), and HepG2 (black) were separated into two groups. Yellow color indicates high levels of gene expression, and blue color indicates low levels of gene expression.

findings indicate that a prediction score lower than Tic's score is associated with low hepatic differentiation propensity, and they suggest that 253G1B1 cells would have a low propensity for hepatic lineage differentiation similar to 201B7 cells, which are known to have a low propensity for hepatocyte differentiation.

The $\Delta \mathrm{Ct}$ values of the three indicator genes in the hPSC lines H9, Tic, 253G1B1 and 201B7 cultured in xeno-free, feeder-free defined hESF-FX medium were compared with those in H9 or 201B7. The prediction score indicated that 253G1B1 may have a low propensity for hepatic differentiation. Comparison of 19-9-7T and its aberrant subclone (19-9-7Tv) cultured under feeder-free conditions using
mTeSR1 medium and Matrigel showed that 19-9-7Tv may have lower propensity for hepatic differentiation compared with the parent line although the prediction score was not calculated with $\mathrm{H} 9$ or 201B7 cultured in the same conditions.

\section{Propensity of hiPSC lines for hepatocyte differentiation}

To further test the predictions for low hepatic differentiation, three high scoring cell lines (H9, KhES3, and KhES4) and two poorly scoring cell lines (253G1B1 and 201B7) were tested for hepatocyte differentiation. 19-9-7T hPSC and its aberrant subclone were also tested.

When maintained under the KSR-based conventional culture conditions with feeder cells, the prediction scores suggested that hepatic differentiation of KhES3 or KhES4 was higher than that of 201B7. H9, KhES3, KhES4, and 201B7 hPSC lines maintained under KSR-based culture conditions were tested for hepatocyte differentiation using the protocol described under Materials and Methods. Morphologies of the differentiated cells are shown in Fig. 3A. Hepatocyte differentiation was measured by albumin secretion, urea production, and CYP3A4 activity (Fig. 3B). By these criteria KhES3 and KhES4 gave rise to more differentiated hepatocyte-like cells than did 201B7 cells.

For cells cultured in hESF-FX the prediction scores suggested that the hepatic differentiation propensity of 253G1B1 was lower than that of H9. We differentiated H9, 253G1B1, and 201B7 cells cultured in hESF-FX medium into hepatocyte-like cells. The differentiated cells were immunostained with antibodies for the hepatocyte markers CYP3A4, albumin and AAT. 253G1B1-derived differentiated cells were partially immunostained with antibodies for CYP3A4, albumin, and AAT whereas 201B7-derived differentiated cells were very poorly stained by these antibodies (Supplementary Fig. S7). Albumin secretion of 253G1B1-derived cells was higher than that of 201B7derived cells but lower than that of H9-derived cells (Fig. 3C). Differentiation levels were also determined by gene expression analysis using the custom PCR array (Fig. 3C and Supplementary Table S6): Hepatocyte markers, such as $A L B$ and G6PC; ATP-binding cassette transporters genes, such as $A B C B 11$ and $A B C C 2 ;$ Cytochrome $P 450$ genes, such as CYP1A1,CYP1A2, and ASGR1; ATT and GSTA1 in 253G1-derived cells was higher than in 201B7derived cells but lower than in H9-derived cells. Hepatic differentiation of 19-9-7T and its aberrant clone, which were established and maintained in mTeSR1 on Matrigel, was also tested. The prediction scores suggested that hepatic differentiation of the aberrant subclone was lower than that of parent line. In fact, albumin secretion, urea production, and CYP3A4 activity of the differentiated aberrant clone were lower than in the differentiated parent clone (Fig. 3D). Our data suggest that low prediction scores based on the expression of the FGF-1, RHOU, and TYMP genes correlate well with low propensity for hepatic differentiation.

\section{Discussion}

In this study we compared expression of genes associated with hepatic differentiation and cell signaling in five undifferentiated hPSCs and their hepatoblast-like 
Table 2. The Value of $\Delta$ Ct for Hepatocyte Lineage- and Signal- Related Gene Expression in Undifferentiated State of Each Human Pluripotent Stem Cell Lines

\begin{tabular}{|c|c|c|c|c|c|c|c|}
\hline \multicolumn{8}{|c|}{ Order correlation $201 B 7<H 9$} \\
\hline \multirow[b]{2}{*}{ Gene } & \multicolumn{7}{|c|}{ Cell line } \\
\hline & $201 B 7$ & Squeaky & Dotcom & Tic & $H 9$ & $A V$ & $S D$ \\
\hline \multicolumn{8}{|c|}{ Hepatocyte lineage-related gene } \\
\hline CYP2E1 & 14.31 & 15.97 & 14.32 & 13.25 & 11.78 & 13.93 & 1.55 \\
\hline$H N F 1 A$ & 17.79 & 16.84 & 15.35 & 13.13 & 15.04 & 15.63 & 1.79 \\
\hline$H N F 1 B$ & 10.66 & 11.25 & 9.51 & 9.15 & 9.24 & 9.96 & 0.94 \\
\hline$H N F 4 A$ & 13.00 & 14.07 & 11.54 & 10.98 & 11.01 & 12.12 & 1.36 \\
\hline ONECUT1 & 10.03 & 9.98 & 9.13 & 7.66 & 8.15 & 8.99 & 1.07 \\
\hline PDX1 & 19.18 & 19.12 & 18.49 & 17.84 & 17.22 & 18.37 & 0.84 \\
\hline \multicolumn{8}{|c|}{ Signal-related gene } \\
\hline CSF2 & 19.92 & 18.80 & 19.18 & 17.88 & 15.85 & 18.32 & 1.56 \\
\hline$F A S L G$ & 19.87 & 19.61 & 19.04 & 19.05 & 17.68 & 19.05 & 0.85 \\
\hline$F G F-1^{*}$ & 9.23 & 8.85 & 9.26 & 8.68 & 7.45 & 8.69 & 0.74 \\
\hline$F G F-17$ & 11.50 & 11.61 & 10.63 & 9.84 & 9.56 & 10.63 & 0.93 \\
\hline$F G F-7$ & 18.24 & 18.26 & 18.32 & 18.17 & 17.88 & 18.17 & 0.17 \\
\hline$M S T N$ & 17.49 & 17.60 & 17.48 & 16.87 & 15.76 & 17.04 & 0.77 \\
\hline $\mathrm{RHOU}^{*}$ & 5.67 & 5.74 & 4.86 & 4.62 & 4.79 & 5.14 & 0.52 \\
\hline$T Y M P^{*}$ & 8.35 & 8.11 & 7.86 & 8.10 & 7.10 & 7.90 & 0.48 \\
\hline
\end{tabular}

Inverse correlation $201 B 7>H 9$

\begin{tabular}{|c|c|c|c|c|c|c|c|}
\hline \multirow[b]{2}{*}{ Gene } & \multicolumn{7}{|c|}{ Cell line } \\
\hline & $201 B 7$ & Squeaky & Dotcom & Tic & $H 9$ & $A V$ & $S D$ \\
\hline \multicolumn{8}{|c|}{ Hepatocyte lineage-related gene } \\
\hline CXCL12 & 2.11 & 2.25 & 2.20 & 2.44 & 2.82 & 2.36 & 0.28 \\
\hline$T F$ & 9.80 & 10.60 & 11.31 & 11.92 & 12.37 & 11.20 & 1.03 \\
\hline \multicolumn{8}{|c|}{ Signal-related gene } \\
\hline$I G F 1$ & 5.71 & 5.58 & 5.52 & 6.52 & 6.14 & 5.89 & 0.42 \\
\hline$P I K 3 R 2$ & 3.97 & 3.72 & 3.80 & 4.12 & 4.03 & 3.93 & 0.16 \\
\hline RHEB & 4.51 & 4.39 & 4.56 & 4.63 & 4.69 & 4.55 & 0.11 \\
\hline SFRP4 & 14.38 & 12.68 & 13.07 & 15.15 & 14.14 & 13.88 & 1.00 \\
\hline
\end{tabular}

Genes that were positively and inversely correlated between undifferentiated hPSCs and hPSC-derived hepatoblast-like cells were summarized. Theses 20 genes were evaluated to lower than 10 in $\Delta \mathrm{Ct}$ values and higher than 0.4 in SD values. According to these criteria three genes, FGF-1, RHOU, and TYMP were selected as candidate genes (*). The mean of gene expression levels of five independent experiments were used for the analysis.

differentiated progeny to develop a method to predict low propensity of hPSC lines for hepatocyte differentiation. Bioinformatics analysis identified 20 genes that were differentially expressed between hPSC lines that differentiated well and poorly into hepatoblast-like cells. We selected three genes, $F G F-1, R H O U$, and TYMP, to test whether their low expression could be used to predict the low ability of hPSCs to differentiate along the hepatic lineage. We investigated expression of these three genes in 23 lines of undifferentiated hPSCs cultured under conventional KSRbased culture conditions or several feeder-free culture conditions, and we calculated prediction scores for hepatic differentiation. The validity of prediction scores of representative cell lines was confirmed by in vitro induction of hepatic differentiation. Our data suggest that low prediction scores were linked with low hepatic differentiation. A previous study reported the propensity for hepatic differentiation using similar hPSC cell lines and found that the propensity for hepatic differentiation decreased as follows: 201B6 > 201B2 > KhES3, H9 > KhES1 > 201B7, 253G1, when maintained under conventional culture conditions
[47]. Our study found that differentiation prediction scores were H9, 201B2, 201B6, KhES3, Dotcom, and Tic $>253 \mathrm{G} 1 \mathrm{~B} 1>201 \mathrm{~B} 7$. These results indicate that our analytical approach can reasonably predict the differentiation propensities of hPSCs.

It is widely understood that hPSC phenotypes are highly variable owing to differences in genomic DNA sequences, DNA methylation status, transcription efficiency, and cell signaling but also because of individual laboratories' culture conditions, culture methods, or culture techniques $[41,65]$. Accumulated differences may determine individual features of hPSC lines. In this study, we hypothesized that hepatocyte differentiation efficiency may differ according to variations in the gene expression profiles of undifferentiated hPSCs. Global gene expression analysis using microarray enables to evaluate stem cell phenotype with potential of lineage-specific differentiation $[43,44]$. Microarray analysis of brown adipocytes derived from wild-type and insulin receptor substrate knockout mice identified a gene expression pattern that predicts brown preadipocyte transition into adipocytes [66]. Because the microarray analyses generate a 
Table 3. Comparison of Three Selected Gene Expression in Undifferentiated State of Each Human Pluripotent Stem Cell Line

\begin{tabular}{|c|c|c|c|c|c|c|}
\hline Cutlure condition/Cell line & $T Y M P$ & $F G F-1$ & RHOU & H9 Point & $201 B 7$ point & Score \\
\hline \multicolumn{7}{|c|}{ KSR-based medium on feeders } \\
\hline \multicolumn{7}{|c|}{ High scores } \\
\hline H9 & 8.5 & 7.05 & 7.22 & 3 & 0 & 3 \\
\hline KhES-5 & $\mathbf{7 . 8 5}$ & 6.84 & 6.98 & 3 & 0 & 3 \\
\hline HES4 & 8.13 & 7.34 & 5.41 & 2 & 0 & 2 \\
\hline TIG120-4f1 & $\mathbf{7 . 9 3}$ & 8.49 & 7.13 & 2 & 0 & 2 \\
\hline KhES-2 & 6.7 & 7.15 & 7.63 & 1 & 0 & 1 \\
\hline KhES-4 & 7.31 & 8.28 & 7.31 & 1 & 0 & 1 \\
\hline 201B2(subclone) & 6.37 & 9.8 & 6.78 & 2 & -1 & 1 \\
\hline Toe & 9.56 & 9.01 & 6.38 & 1 & 0 & 1 \\
\hline UTA1 & 8.37 & 9.67 & 5.85 & 2 & -1 & 1 \\
\hline KhES-1 & 8.32 & 9.09 & 7.84 & 1 & 0 & 1 \\
\hline 201B6 & 8.95 & 8.79 & 7.76 & 0 & 0 & 0 \\
\hline KhES-3 & 8.92 & 8.84 & 7.54 & 0 & 0 & 0 \\
\hline 201B2 & 8.41 & 9.76 & 7.53 & 1 & -1 & 0 \\
\hline TIG114-4f1 & 7.56 & 10.59 & 7.43 & 1 & -1 & 0 \\
\hline TIG108-4f3 & 8.4 & 9.59 & 7.64 & 1 & -1 & 0 \\
\hline Dotcom & 9.14 & 8.11 & 7.55 & 0 & 0 & 0 \\
\hline Tic & 10.55 & 8.07 & 7.16 & 1 & -1 & 0 \\
\hline \multicolumn{7}{|l|}{ Low scores } \\
\hline Squeaky & 9.95 & 7.16 & 8.36 & 0 & -1 & -1 \\
\hline $253 \mathrm{G} 1 \mathrm{~B} 1$ & 9.69 & 9.9 & 9.31 & 0 & -2 & -2 \\
\hline $201 \mathrm{~B} 7$ & 9.94 & 9.34 & 8.97 & 0 & -3 & -3 \\
\hline \multirow{2}{*}{\multicolumn{7}{|c|}{$\begin{array}{l}\text { hESF-FX medium without feeders } \\
\text { High scores }\end{array}$}} \\
\hline & & & & & & \\
\hline H9 & 8.08 & 8.09 & 4.89 & 3 & 0 & 3 \\
\hline & 8.4 & 11.82 & 4.74 & 1 & -1 & 0 \\
\hline \multicolumn{7}{|l|}{ Low scores } \\
\hline 253G1B1 & 9.81 & 7.86 & 6.62 & 1 & -2 & -1 \\
\hline $201 \mathrm{~B} 7$ & 9.33 & 10.01 & 6.25 & 0 & -3 & -3 \\
\hline \multicolumn{7}{|c|}{ mTeSR1 medium without feeders } \\
\hline 19-9-7T normal & 6.89 & 9.5 & 6.43 & ND & ND & ND \\
\hline 19-9-7T abnormal & 7.3 & 8.93 & 7.29 & ND & ND & ND \\
\hline
\end{tabular}

The expression ratios listed in bold are lower than that of $\mathrm{H} 9$, and the ratios listed in italic are higher than that of $201 \mathrm{~B} 7$.

The mean of gene expression levels of three independent experiments were used for the analysis.

KSR, knockout serum replacement; ND, not determined.

large amount of data, providing a tremendous number of candidate genes some of which are nonfunctional, a large of time, labor, and cost are required to identify objective genes. Therefore, we focused on genes previously reported to be associated with endoderm or hepatic differentiation pathways. Several hepatic differentiation protocols indicated that endoderm specification from hPSCs is driven by a combination of several growth factors including BMP, NODAL/ACTIVIN A, FGF, and WNT [13,26-31]. These growth factors stimulate intracellular signaling, such as MAPK, PI3K-AKT, ERK, and GSK3B signals. Therefore, we used a PCR array system including genes related to hepatocyte differentiation markers, PI3K-AKTsignaling pathway, TGF $\beta /$ BMP signaling pathway, growth factors, or WNT signaling pathway. From these gene expression profiles, three genes, TYMP, FGF-1, and RHOU, were selected as candidates that may predict the hepatic differentiation efficiency of hPSC lines. TYMP is also known as plateletderived endothelial cell growth factor and plays a role in maintaining the integrity of blood vessels, promoting endothelial growth and angiogenesis in vivo, and promoting the chemotactic activity of endothelial cells in vitro [67].
TYMP expression is reported to be elevated in liver, lung, and breast tumors [68]. FGF-1, a member of the FGF family, is known to be involved in vertebrate embryonic and fetal development [69]. RHOU is implicated in the connection between $\beta$-catenin-dependent WNT signaling and cellular processes normally associated with WNT/PCP pathways [70]. These findings implicate these genes in the regulation of differentiation toward hepatocytes. We aim to further investigate the function of these genes in future studies.

Several highly efficient methods for inducing differentiation of hPSCs into hepatocytes have been proposed [39,7174]. On the other hand, an enormous number of hiPSCs with variable phenotypes are generated from various donors in several institutes in the world. Ideally, hPSCs possess the potential to differentiate into cells of all three germ layers. However, in practice, hPSC differentiation propensity is limited to specific lineages. Developing a method to select good clones would be immensely useful. Several previous studies have proposed bioinformatic assay platforms capable of predicting hPSCs phenotypes $[43,44]$. These assays used embryoid bodies (EBs) to evaluate propensity to differentiate into the three germ layers. We first tried to 

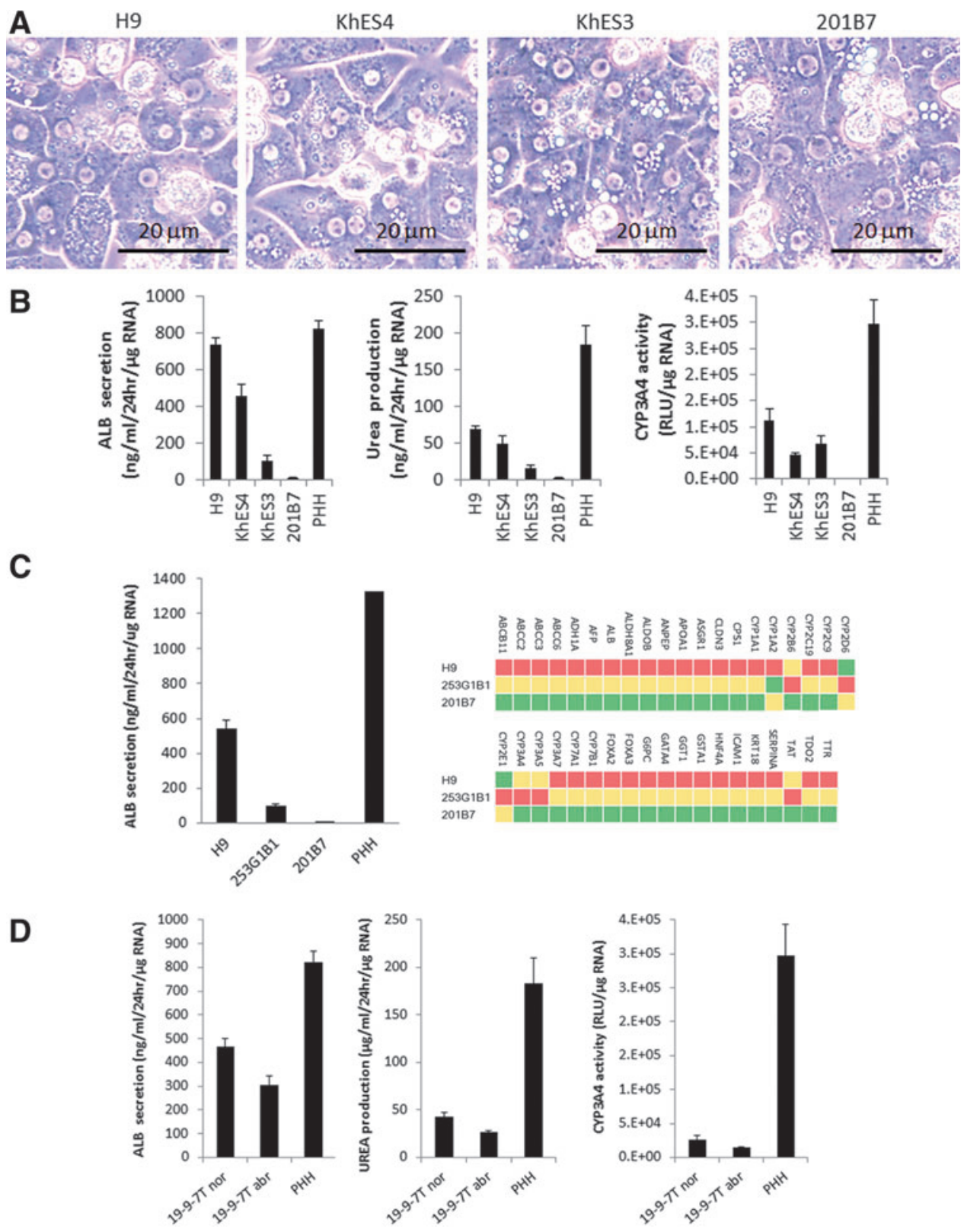

FIG. 3. Hepatic differentiation of the hPSC line predicted a low differentiation tendency. (A) Phase contrast images of hepatocyte-like cells derived from hPSCs, H9, KhES-4, KhES-4, and 201B7 maintained under conventional KSR-based culture condition with feeder cells were shown. Scale bars $=20 \mu \mathrm{m}$. (B) albumin secretion, urea production, and CYP3A4 activity of these cells and primary human hepatocytes $(\mathrm{PHH})$ were examined. The results are presented as the mean of three biological independent experiments, and error bars represent SD. (C) Left: albumin secretion from hepatocyte-like cells derived from hPSCs H9, 253G1B1, and 201B7 cultured under feeder-free culture conditions were examined by ELISA on differentiation day 20. Concentration was calculated using a standard reagent followed by normalization to the total RNA content. The results are presented as the mean of three biological independent experiments, and error bars represent SD. Right: custom polymerase chain reaction array analysis of these hepatocyte-like cells. Each gene expression level is compared among three lines (red > yellow $>$ green). The mean of gene expression levels of three independent experiments were used for the analysis. (D) Albumin secretion, urea production, and CYP3A4 activity of 19-9-7T, its aberrant clone (199-7T abr) and primary human hepatocytes (PHH) were examined. The results are presented as the mean of three biological independent experiments, and error bars represent SD. KSR, knockout serum replacement.

examine the propensity of five hPSC cell lines, H9, 201B7, Tic, Dotcom, and Squeaky, to differentiate into three germ layers using a Human Stem Cell Pluripotency Array, as described previously [41] (Supplementary Table S6). Expression of endoderm marker in EBs derived from Tic and Dotcom was higher than in Squeaky, and expression in H9 was similar to that in 201B7 (Supplementary Table S7). Stem cell marker expression was lower in $\mathrm{H} 9$, Tic, and Squeaky than in 201B7. However, scoring of genes associated with hepatic differentiation, tyrosine aminotransferase (TAT), alpha-fetoprotein (AFP), forkhead box protein A2 (FOXA2), serpin peptidase inhibitor, clade A member 1 
(SERPINA1; known as AAT), and SRY-related HMG-box 17 (SOX17), indicated that autonomous hepatic differentiation propensity decreased from Tic $>$ Dotcom $>201 B 7>$ H9 $>$ Squeaky (Supplementary Table S8). However, 201B7 was previously reported to have a low hepatic propensity [47], whereas $\mathrm{H} 9$ is reported to have high hepatic propensity $[27,30,31,75]$. Our results were consistent with these reports [35,38], indicating that autonomous differentiation, by forming $\mathrm{EB}$, is not associated with hepatocyte differentiation induced by the specific protocols we employed. Neural or mesoderm differentiation is autonomously promoted. On the other hand, endoderm differentiation requires high doses of specific growth factors at specific timing. It may be difficult to predict endoderm differentiation propensity based on EB gene expression data alone.

\section{Conclusions}

We hypothesized that hepatocyte differentiation efficiency of hPSC can be predicted by analyzing the gene expression profile in undifferentiated hPSCs. We were concerned that the large quantity of data generated by global gene microarrays may fail to highlight minute differences in hPSC phenotypes. Instead, we assessed the expression levels of selected genes previously reported to be associated with hepatic differentiation and cell signaling. Clustering analyses of five hPSC lines identified three candidate genes. In this study, we estimated the prediction scores for differentiation propensity of $23 \mathrm{hPSC}$ clones compared with those of H9 or 201B7 hPSC lines. Our analytical approach proposed a method for prediction method using gene expression ranking and bioinformatic analysis. The reliability of this method could be assessed by examining more hPSC lines, and additional reliable markers could be identified. If hPSC gene expression profiles were provided by international public stem cell banks or related platforms, it may be possible to identify more hPSC lines with lower hepatic differentiation propensity.

\section{Acknowledgments}

We thank Hiroko Eimori, Mari Wakabayashi, and Naoko Ueda for excellent technical support. We would like to thank Dr. J.D. Sato for the English language and scientific review. This study was supported by grants-in-aid from the Ministry of Health, Labor, and Welfare of Japan and the Japan Agency for Medical Research and Development (AMED) to M.K.F. and the Ministry of Education, Culture, Sports, Science, and Technology of Japan to K.Y., M.K.F., and M.S.

\section{Author Disclosure Statement}

No competing financial interests exist.

\section{References}

1. Thomson JA, J Itskovitz-Eldor, SS Shapiro, MA Waknitz, JJ Swiergiel, VS Marshall and JM Jones. (1998). Embryonic stem cell lines derived from human blastocysts. Science 282:1145-1147.

2. Takahashi $\mathrm{K}$ and S Yamanaka. (2006). Induction of pluripotent stem cells from mouse embryonic and adult fibroblast cultures by defined factors. Cell 126:663676.

3. Takahashi K, K Tanabe, M Ohnuki, M Narita, T Ichisaka, K Tomoda and S Yamanaka. (2007). Induction of pluripotent stem cells from adult human fibroblasts by defined factors. Cell 131:861-872.

4. Murry CE and G Keller. (2008). Differentiation of embryonic stem cells to clinically relevant populations: lessons from embryonic development. Cell 132:661-680.

5. Barbaric I, PJ Gokhale and PW Andrews. (2010). Highcontent screening of small compounds on human embryonic stem cells. Biochem Soc Trans 38:1046-1050.

6. Engle SJ and D Puppala. (2013). Integrating human pluripotent stem cells into drug development. Cell Stem Cell 12:669-677.

7. Heslop JA, C Rowe, J Walsh, R Sison-Young, R Jenkins, L Kamalian, R Kia, D Hay, RP Jones, et al. (2016). Mechanistic evaluation of primary human hepatocyte culture using global proteomic analysis reveals a selective dedifferentiation profile. Arch Toxicol [Epub ahead of print]; DOI:10.1007/s00204-016-1694-y.

8. Rashid ST, S Corbineau, N Hannan, SJ Marciniak, E Miranda, G Alexander, I Huang-Doran, J Griffin, L Ahrlund-Richter, et al. (2010). Modeling inherited metabolic disorders of the liver using human induced pluripotent stem cells. J Clin Invest 120:3127-3136.

9. Cayo MA, J Cai, A DeLaForest, FK Noto, M Nagaoka, BS Clark, RF Collery, K Si-Tayeb and SA Duncan. (2012). JD induced pluripotent stem cell-derived hepatocytes faithfully recapitulate the pathophysiology of familial hypercholesterolemia. Hepatology 56:2163-2171.

10. Roelandt P, S Obeid, J Paeshuyse, J Vanhove, A Van Lommel, Y Nahmias, F Nevens, J Neyts and CM Verfaillie. (2012). Human pluripotent stem cell-derived hepatocytes support complete replication of hepatitis $\mathrm{C}$ virus. J Hepatol 57:246-251.

11. Wu X, JM Robotham, E Lee, S Dalton, NM Kneteman, DM Gilbert and H Tang. (2012). Productive hepatitis C virus infection of stem cell-derived hepatocytes reveals a critical transition to viral permissiveness during differentiation. PLoS Pathog 8:e1002617.

12. Zhou X, P Sun, B Lucendo-Villarin, AG Angus, D Szkolnicka, K Cameron, SL Farnworth, AH Patel and DC Hay. (2014). Modulating innate immunity improves hepatitis C virus infection and replication in stem cell-derived hepatocytes. Stem Cell Reports 3:204-214.

13. Sullivan GJ, DC Hay, IH Park, J Fletcher, Z Hannoun, CM Payne, D Dalgetty, JR Black, JA Ross, et al. (2010). Generation of functional human hepatic endoderm from human induced pluripotent stem cells. Hepatology 51: 329-335.

14. Anson BD, KL Kolaja and TJ Kamp. (2011). Opportunities for use of human iPS cells in predictive toxicology. Clin Pharmacol Ther 89:754-758.

15. Medine CN, B Lucendo-Villarin, C Storck, F Wang, D Szkolnicka, F Khan, S Pernagallo, JR Black, HM Marriage, et al. (2013). Developing high-fidelity hepatotoxicity models from pluripotent stem cells. Stem Cells Transl Med 2:505-509.

16. Holmgren G, AK Sjogren, I Barragan, A Sabirsh, P Sartipy, J Synnergren, $\mathrm{P}$ Bjorquist, M Ingelman-Sundberg, TB Andersson and J Edsbagge. (2014). Long-term chronic toxicity testing using human pluripotent stem cell-derived hepatocytes. Drug Metab Dispos 42:1401-1406. 
17. Szkolnicka D, SL Farnworth, B Lucendo-Villarin, C Storck, W Zhou, JP Iredale, O Flint and DC Hay. (2014). Accurate prediction of drug-induced liver injury using stem cell-derived populations. Stem Cells Transl Med 3: 141-148.

18. Szkolnicka D, B Lucendo-Villarin, JK Moore, KJ Simpson, SJ Forbes and DC Hay. (2016). Reducing hepatocyte injury and necrosis in response to paracetamol using noncoding RNAs. Stem Cells Transl Med 5:764-772.

19. Rashidi H, S Alhaque, D Szkolnicka, O Flint and DC Hay. (2016). Fluid shear stress modulation of hepatocyte-like cell function. Arch Toxicol 90:1757-1761.

20. Villarin BL, K Cameron, D Szkolnicka, H Rashidi, N Bates, SJ Kimber, O Flint, SJ Forbes, JP Iredale, M Bradley and DC Hay. (2015). Polymer supported directed differentiation reveals a unique gene signature predicting stable hepatocyte performance. Adv Healthc Mater 4:18201825.

21. Lavon N, O Yanuka and N Benvenisty. (2004). Differentiation and isolation of hepatic-like cells from human embryonic stem cells. Differentiation 72:230-238.

22. Duan Y, A Catana, Y Meng, N Yamamoto, S He, S Gupta, SS Gambhir and MA Zern. (2007). Differentiation and enrichment of hepatocyte-like cells from human embryonic stem cells in vitro and in vivo. Stem Cells 25:3058-3068.

23. Hay DC, D Zhao, A Ross, R Mandalam, J Lebkowski and W Cui. (2007). Direct differentiation of human embryonic stem cells to hepatocyte-like cells exhibiting functional activities. Cloning Stem Cells 9:51-62.

24. Hay DC, J Fletcher, C Payne, JD Terrace, RC Gallagher, J Snoeys, JR Black, D Wojtacha, K Samuel, et al. (2008). Highly efficient differentiation of hESCs to functional hepatic endoderm requires ActivinA and Wnt3a signaling. Proc Natl Acad Sci U S A 105:12301-12306.

25. Fletcher J, W Cui, K Samuel, JR Black, Z Hannoun, IS Currie, JD Terrace, C Payne, C Filippi, et al. (2008). The inhibitory role of stromal cell mesenchyme on human embryonic stem cell hepatocyte differentiation is overcome by Wnt3a treatment. Cloning Stem Cells 10:331-339.

26. Agarwal S, KL Holton and R Lanza. (2008). Efficient differentiation of functional hepatocytes from human embryonic stem cells. Stem Cells 26:1117-1127.

27. Hay DC, D Zhao, J Fletcher, ZA Hewitt, D McLean, A Urruticoechea-Uriguen, JR Black, C Elcombe, JA Ross, R Wolf and W Cui. (2008). Efficient differentiation of hepatocytes from human embryonic stem cells exhibiting markers recapitulating liver development in vivo. Stem Cells 26:894-902.

28. Shiraki N, K Umeda, N Sakashita, M Takeya, K Kume and S Kume. (2008). Differentiation of mouse and human embryonic stem cells into hepatic lineages. Genes Cells 13:731-746.

29. Song Z, J Cai, Y Liu, D Zhao, J Yong, S Duo, X Song, Y Guo, Y Zhao, et al. (2009). Efficient generation of hepatocyte-like cells from human induced pluripotent stem cells. Cell Res 19:1233-1242.

30. Touboul T, NR Hannan, S Corbineau, A Martinez, C Martinet, S Branchereau, S Mainot, H Strick-Marchand, R Pedersen, et al. (2010). Generation of functional hepatocytes from human embryonic stem cells under chemically defined conditions that recapitulate liver development. Hepatology 51:1754-1765.

31. Si-Tayeb K, FK Noto, M Nagaoka, J Li, MA Battle, C Duris, PE North, S Dalton and SA Duncan. (2010). Highly efficient generation of human hepatocyte-like cells from induced pluripotent stem cells. Hepatology 51:297-305.

32. Godoy P, W Schmidt-Heck, K Natarajan, B LucendoVillarin, D Szkolnicka, A Asplund, P Bjorquist, A Widera, R Stober, et al. (2015). Gene networks and transcription factor motifs defining the differentiation of stem cells into hepatocyte-like cells. J Hepatol 63:934-942.

33. Cameron K, R Tan, W Schmidt-Heck, G Campos, MJ Lyall, Y Wang, B Lucendo-Villarin, D Szkolnicka, N Bates, et al. (2015). Recombinant laminins drive the differentiation and self-organization of hESC-derived hepatocytes. Stem Cell Reports 5:1250-1262.

34. Inamura M, K Kawabata, K Takayama, K Tashiro, F Sakurai, K Katayama, M Toyoda, H Akutsu, Y Miyagawa, et al. (2011). Efficient generation of hepatoblasts from human ES cells and iPS cells by transient overexpression of homeobox gene HEX. Mol Ther 19:400-407.

35. Takayama K, M Inamura, K Kawabata, K Tashiro, K Katayama, F Sakurai, T Hayakawa, MK Furue and H Mizuguchi. (2011). Efficient and directive generation of two distinct endoderm lineages from human ESCs and iPSCs by differentiation stage-specific SOX17 transduction. PLoS One 6:e21780.

36. Nagamoto $\mathrm{Y}, \mathrm{K}$ Tashiro, $\mathrm{K}$ Takayama, K Ohashi, K Kawabata, F Sakurai, M Tachibana, T Hayakawa, MK Furue and H Mizuguchi. (2012). The promotion of hepatic maturation of human pluripotent stem cells in 3D coculture using type I collagen and Swiss 3T3 cell sheets. Biomaterials 33:4526-4534.

37. Takayama K, M Inamura, K Kawabata, K Katayama, M Higuchi, K Tashiro, A Nonaka, F Sakurai, T Hayakawa, MK Furue and H Mizuguchi. (2012). Efficient generation of functional hepatocytes from human embryonic stem cells and induced pluripotent stem cells by HNF4alpha transduction. Mol Ther 20:127-137.

38. Takayama K, M Inamura, K Kawabata, M Sugawara, K Kikuchi, M Higuchi, Y Nagamoto, H Watanabe, K Tashiro, et al. (2012). Generation of metabolically functioning hepatocytes from human pluripotent stem cells by FOXA2 and HNF1alpha transduction. J Hepatol 57:628-636.

39. Watanabe H, K Takayama, M Inamura, M Tachibana, $N$ Mimura, K Katayama, K Tashiro, Y Nagamoto, F Sakurai, et al. (2014). HHEX promotes hepatic-lineage specification through the negative regulation of eomesodermin. PLoS One 9:e90791.

40. Tashiro K, K Kawabata, M Inamura, K Takayama, N Furukawa, F Sakurai, K Katayama, T Hayakawa, MK Furue and H Mizuguchi. (2010). Adenovirus vector-mediated efficient transduction into human embryonic and induced pluripotent stem cells. Cell Reprogram 12:501-507.

41. International Stem Cell Initiative, O Adewumi, B Aflatoonian, L Ahrlund-Richter, M Amit, PW Andrews, G Beighton, PA Bello, N Benvenisty, LS Berry, et al. (2007). Characterization of human embryonic stem cell lines by the International Stem Cell Initiative. Nat Biotechnol 25: 803-816.

42. Osafune K, L Caron, M Borowiak, RJ Martinez, CS FitzGerald, Y Sato, CA Cowan, KR Chien and DA Melton. (2008). Marked differences in differentiation propensity among human embryonic stem cell lines. Nat Biotechnol 26:313-315.

43. Bock C, E Kiskinis, G Verstappen, H Gu, G Boulting, ZD Smith, M Ziller, GF Croft, MW Amoroso, et al. (2011). Reference maps of human ES and iPS cell variation enable 
high-throughput characterization of pluripotent cell lines. Cell 144:439-452.

44. Muller FJ, BM Schuldt, R Williams, D Mason, G Altun, EP Papapetrou, S Danner, JE Goldmann, A Herbst, et al. (2011). A bioinformatic assay for pluripotency in human cells. Nat Methods 8:315-317.

45. Koyanagi-Aoi M, M Ohnuki, K Takahashi, K Okita, H Noma, Y Sawamura, I Teramoto, M Narita, Y Sato, et al. (2013). Differentiation-defective phenotypes revealed by large-scale analyses of human pluripotent stem cells. Proc Natl Acad Sci U S A 110:20569-20574.

46. Baxter M, S Withey, S Harrison, CP Segeritz, F Zhang, R Atkinson-Dell, C Rowe, DT Gerrard, R Sison-Young, et al. (2015). Phenotypic and functional analyses show stem cellderived hepatocyte-like cells better mimic fetal rather than adult hepatocytes. J Hepatol 62:581-589.

47. Kajiwara M, T Aoi, K Okita, R Takahashi, H Inoue, $\mathrm{N}$ Takayama, H Endo, K Eto, J Toguchida, S Uemoto and S Yamanaka. (2012). Donor-dependent variations in hepatic differentiation from human-induced pluripotent stem cells. Proc Natl Acad Sci U S A 109:1253812543.

48. Lee SB, D Seo, D Choi, KY Park, A Holczbauer, JU Marquardt, EA Conner, VM Factor and SS Thorgeirsson. (2012). Contribution of hepatic lineage stage-specific donor memory to the differential potential of induced mouse pluripotent stem cells. Stem Cells 30:997-1007.

49. Ishikawa T, M Kobayashi, S Yanagi, C Kato, R Takashima, E Kobayashi, K Hagiwara and T Ochiya. (2015). Human induced hepatic lineage-oriented stem cells: autonomous specification of human iPS cells toward hepatocyte-like cells without any exogenous differentiation factors. PLoS One 10:e0123193.

50. Itaba N, PM Wairagu, N Aramaki, T Yasui, Y Matsumi, Y Kono, AN Phan, M Otsu, T Kunisada, et al. (2014). Nuclear receptor gene alteration in human induced pluripotent stem cells with hepatic differentiation propensity. Hepatol Res 44:E408-E419.

51. Amit M, MK Carpenter, MS Inokuma, CP Chiu, CP Harris, MA Waknitz, J Itskovitz-Eldor and JA Thomson. (2000). Clonally derived human embryonic stem cell lines maintain pluripotency and proliferative potential for prolonged periods of culture. Dev Biol 227: 271-278.

52. Nishino K, M Toyoda, M Yamazaki-Inoue, Y Fukawatase, E Chikazawa, H Sakaguchi, H Akutsu and A Umezawa. (2011). DNA methylation dynamics in human induced pluripotent stem cells over time. PLoS Genet 7: e1002085.

53. Kinehara M, S Kawamura, D Tateyama, M Suga, H Matsumura, S Mimura, N Hirayama, M Hirata, K UchioYamada, et al. (2013). Protein kinase C regulates human pluripotent stem cell self-renewal. PLoS One 8:e54122.

54. Furue MK and M Kinehara. (KYOWA HAKKO BIO CO., LTD., JAPAN). Method for culturing human pluripotent stem cells. PCT/JP2011/004691, WO2012104936A1

55. Furue MK, J Na, JP Jackson, $\mathrm{T}$ Okamoto, M Jones, D Baker, R Hata, HD Moore, JD Sato and PW Andrews. (2008). Heparin promotes the growth of human embryonic stem cells in a defined serum-free medium. Proc Natl Acad Sci U S A 105:13409-13414.

56. Kinehara M, S Kawamura, S Mimura, M Suga, A Hamada, M Wakabayashi, H Nikawa and MK Furue. (2014). Protein kinase $\mathrm{C}$-induced early growth response protein-1 binding to SNAIL promoter in epithelial-mesenchymal transition of human embryonic stem cells. Stem Cells Dev 23:21802189.

57. Mimura S, M Suga, Y Liu, M Kinehara, K Yanagihara, K Ohnuma, H Nikawa and MK Furue. (2015). Synergistic effects of FGF-2 and Activin A on early neural differentiation of human pluripotent stem cells. In Vitro Cell Dev Biol Anim 51:769-775.

58. Mimura S, M Suga, K Okada, M Kinehara, H Nikawa and MK Furue. (2016). Bone morphogenetic protein 4 promotes craniofacial neural crest induction from human pluripotent stem cells. Int J Dev Biol 60:21-28.

59. Hannan NR, RP Fordham, YA Syed, V Moignard, A Berry, R Bautista, NA Hanley, KB Jensen and L Vallier. (2013). Generation of multipotent foregut stem cells from human pluripotent stem cells. Stem Cell Reports 1: 293-306.

60. Cai J, A DeLaForest, J Fisher, A Urick, T Wagner, K Twaroski, M Cayo, M Nagaoka and SA Duncan. (2012). Protocol for directed differentiation of human pluripotent stem cells toward a hepatocyte fate. StemBook, ed. The Stem Cell Research Community, In StemBook. Cambridge, MA. doi/10.3824/stembook.1.52.1, http://www.stembook.org.

61. Mallanna SK and SA Duncan. (2013). Differentiation of hepatocytes from pluripotent stem cells. Curr Protoc Stem Cell Biol 26:Unit 1G 4.

62. Takayama K, Y Morisaki, S Kuno, Y Nagamoto, K Harada, N Furukawa, M Ohtaka, K Nishimura, K Imagawa, et al. (2014). Prediction of interindividual differences in hepatic functions and drug sensitivity by using human iPSderived hepatocytes. Proc Natl Acad Sci U S A 111:1677216777.

63. Schena M. (2002). Microarray Analysis. John Wiley \& Sons, Inc., Hoboken, NJ.

64. Knudsen S. (2004). Guide to Analysis of DNA Microarray Data, 2nd edn. John Wiley \& Sons, Inc., Hoboken, NJ.

65. International Stem Cell Initiative, K Amps, PW Andrews, G Anyfantis, L Armstrong, S Avery, H Baharvand, J Baker, D Baker, MB Munoz, et al. (2011). Screening ethnically diverse human embryonic stem cells identifies a chromosome 20 minimal amplicon conferring growth advantage. Nat Biotechnol 29:1132-1144.

66. Tseng YH, AJ Butte, E Kokkotou, VK Yechoor, CM Taniguchi, KM Kriauciunas, AM Cypess, M Niinobe, K Yoshikawa, ME Patti and CR Kahn. (2005). Prediction of preadipocyte differentiation by gene expression reveals role of insulin receptor substrates and necdin. Nat Cell Biol 7:601-611.

67. Usuki K, J Saras, J Waltenberger, K Miyazono, G Pierce, A Thomason and CH Heldin. (1992). Platelet-derived endothelial cell growth factor has thymidine phosphorylase activity. Biochem Biophys Res Commun 184:13111316.

68. Yoshimura A, Y Kuwazuru, T Furukawa, H Yoshida, K Yamada and S Akiyama. (1990). Purification and tissue distribution of human thymidine phosphorylase; high expression in lymphocytes, reticulocytes and tumors. Biochim Biophys Acta 1034:107-113.

69. Bottcher RT and C Niehrs. (2005). Fibroblast growth factor signaling during early vertebrate development. Endocr Rev 26:63-77.

70. Loebel DA and PP Tam. (2012). Rho GTPases in endoderm development and differentiation. Small GTPases $3: 40-44$. 
71. Shan J, RE Schwartz, NT Ross, DJ Logan, D Thomas, SA Duncan, TE North, W Goessling, AE Carpenter and SN Bhatia. (2013). Identification of small molecules for human hepatocyte expansion and iPS differentiation. Nat Chem Biol 9:514-520.

72. Nagaoka M, M Kobayashi, C Kawai, SK Mallanna and SA Duncan. (2015). Design of a vitronectin-based recombinant protein as a defined substrate for differentiation of human pluripotent stem cells into hepatocyte-like cells. PLoS One 10:e0136350.

73. Twaroski K, SK Mallanna, R Jing, F DiFurio, A Urick and SA Duncan. (2015). FGF2 mediates hepatic progenitor cell formation during human pluripotent stem cell differentiation by inducing the WNT antagonist NKD1. Genes Dev 29:2463-2474.

74. Sampaziotis F, M Cardoso de Brito, P Madrigal, A Bertero, K Saeb-Parsy, FA Soares, E Schrumpf, E Melum, TH Karlsen, et al. (2015). Cholangiocytes derived from human induced pluripotent stem cells for disease modeling and drug validation. Nat Biotechnol 33:845-852.
75. Cai J, Y Zhao, Y Liu, F Ye, Z Song, H Qin, S Meng, Y Chen, R Zhou, et al. (2007). Directed differentiation of human embryonic stem cells into functional hepatic cells. Hepatology 45:1229-1239.

$$
\begin{array}{r}
\text { Address correspondence to: } \\
\text { Dr. Miho K. Furue } \\
\text { Laboratory of Stem Cell Cultures } \\
\text { National Institutes of Biomedical Innovation, } \\
\text { Health and Nutrition } \\
\text { Ibaraki } \\
\text { Osaka 567-0085 } \\
\text { Japan }
\end{array}
$$

E-mail: mkfurue@nibiohn.go.jp; mkfurue@gmail.com

Received for publication April 28, 2016

Accepted after revision October 7, 2016

Prepublished on Liebert Instant Online October 12, 2016 